JIEBAR : Journal of Islamic Education: Basic and Applied Research Vol. 01, Nomor 02, Oktober 2020

\title{
The Role of Parents in Educating Children in the Industrial Revolution Era 4.0
}

\section{Peran Orang Tua dalam Mendidik Anak Di Era Revolusi Industri 4.0}

\author{
Yuda Rudiana \\ Program Studi Pendidikan Agama Islam, STIT Islamic Village Tangerang \\ Email: Yudharudiana69@gmail.com
}

Received: September, 2020.

Accepted: September, 2020.

Published: Oktober, 2020.

\begin{abstract}
Mini thesis, Islamic Education Department, July 2020. These research objectives held to know how the parent's concept of educating children in the industrial revolution era 4.0, in Kp. Undrus, Cijantra Village, Kab. Tangerang also to know the parents' obstacle factor on the process that educating children in the industrial revolution era 4,0, in Kp. Undrus, Cijantra Village, Kab. Tangerang. This research used a field study approach in Kp. Undrus, Cijantra Village, Kab. Tangerang. The technique's data collection in this research used observation, interview, and documentation. While the data analysis used data collection, data presentation, data reduction, and data verification or taken conclusion. Then, used a validity test technique with the prioritize as data credibility, data transferability, real power, also a confirmation research object. This research result indicates that the parent has an important role in preparing for the industrial revolution 4.0. Through education has done parents in a family by various ways as harmonization the relation of parentchild, became examples to children, motivate and support to the in learning, and have a clear purpose be parents in Kp. Undrus, Cijantra Village, Kab. Tangerang in educating children in the industrial revolution 4.0. children education by the parents have to deficient in economy providing media learning, lack of understanding matter learning child by the parents and lack of compliance to parents.
\end{abstract}

Keywords: Family Educated; Industrial Revolution Era

\section{ABSTRAK}

Tujuan penelitian ini dilaksanakan untuk mengetabui bagaimana konsep orang tua dalam mendidik anak pada Era Revolusi Industri 4.0, di Kp Undrus, Desa Cijantra, Kab Tangerang serta untuk mengetabui faktor penghambat orang tua dalam proses mendidik anak pada Era 
Revolusi Industri 4.0, di Kp Undrus, Desa Cijantra, Kah Tangerang. Penelitian ini mengganakan pendekatan berupa studi lapangan di Kp. Undrus, Desa Cijantra, Kab Tangerang Teknik pengumpulan data pada penelitian ini menggunakan obnervasi, wawancara, dan dokumentasi Sedangkan analinis data yang reduksi data, dan verifikasi data stau penurikan kesimpulan. Lalu menggunakan teknik ui validitas data dengan mengutamakan kredibilitas data, transferabilitas data, kekuatan realitas, serta konfirmasi objek penelitian. Hasil penelitian ini menunjukkan bahwa orang tua memiliki peranan yang penting dalam mempersiapkan anak di era Revolusi Industri 4.0. Melalui pendidikan yang dilakukan orang tua di dalam keluarga dengan berbagai cara seperti harmonisasi hubungan orang tua dengan anak, menjadi teladan untuk anak memberikan motivasi dan dukungan kepada anak dalam belajar, serta memiliki tujuan yang jelas merupakan cara orang tua di Kp. Undrus, Desa Cijantra-Kab. Tangerang dalam mendidik anak di era Revolusi Industri 4.0. Pendidikan anak yang dilakukan oleh orang tua memiliki kendala seperti kekurangan dalam bidang ekonomi untuk penyediaan media pembelajaran, kurangnya pemahaman materi pembelajaran anak oleh orang tua serta kurangnya kepatuban anak terhadap orang tua.

Kata Kunci: Pendidikan Keluarga, Revolusi Industri 4.0

\section{PENDAHULUAN}

Pada akhir abad ke 21 ini secara jelas timbul dampak yang banyak sehingga munculnya fenomena dismptive inovation yang yang menyebar kepada seluruh kehidupan seperti bidang industri, ekonomi, pendidikan dan politik serta berdampak juga kepada bergesernya gaya hidup dan mindset masyarakat di seluruh dunia (Priatmoko, 2018:230). Contohya, segala kehidupan yang ada sekarang ini hampir tergantikan oleh mesin, seperti check barang sudah dilakukan oleh mesin, pemindai visa juga sudah menggunakan mesin. Dari dua contoh tersebut dapat dikatakan bahwa mesin sudah menjadi bagian pada kehidupan manusia.

Percepatan akses teknologi serta kemudahan berinteraksi menjadikan seolah dunia semakin kecil, seperti di dalam genggaman manusia, dalam perkembangan digitalisasi sudah tercabut dari akar aktivitas manusia, kini mesin bukan sebagai penggerak ekonomi saja namun sudah masuk ke sektor ilmu pengetahuan dibidang pendidikan. Hal ini perlu adanya perumusan yang lebih serius mengenai badan organisasi, mata pelajaran, perangkat dan bahan ajar, serta kesiapan untuk pengembangan yang lebih menginovasi pembelajaran (Maemunah, 2018:3).

JIEBAR : Journal of Islamic Education: Basic and Applied Research Vol. 01, Nomor 02, Oktober2020 
Seluruh stakeholder yang dapat berpengaruh dalam lingkungan seperti orang tua, peserta didik, pendidik, pengawas pendidikan dan masyarakat, kiranya harus mendapatkan berita tentang peningkatan atau penurunan sistem pendidikan di negaranya dalam mempersiapkan peserta didik agar mampu bersaing di abad ke 21 (Syamsuar \& Reflianto, 2019:3). Memang ini bukan tugas yang kecil dalam menentukan arah keberhasilan, tentu setiap orang harus ada campur tangan dari orang lain. Mustahil jika seseorang dapat sukses dan berhasil dengan sedirinya untuk mencapai tujuan yang ingin didapatkan.

Orang tua tentunya dituntut untuk dapat menselaraskan cara mendidik anak dengan perkembangan zaman masa kini sesuai dengan kebutuhannya. Dengan memahami bagaimana konsep dan tujuan pendidikan yang ada serta kebutuhan akan manusia yang ahli dalam bidang teknologi pada sektor manapun (Syamsuar \& Reflianto, 2019:3). Perubahan yang terjadi pada masa kini sangat berpengaruh terhadap kepribadian manusia serta atau tidaknya seseorang dapat belajar dengan sangat cepat mengenai perubahanperubahan tersebut. Ini menjadi sebuah tantangan yang perlu dihadapi bagi orang tua sebagai modal pendidikan utama untuk menciptakan generasi yang benar-benar siap kerja dan ahli pada bidangnya dalam memanfaatkan kecanggihan teknologi dan informasi (Syamsuar \& Reflianto, 2019:4).

\section{METODE PENELITIAN}

Penelitian ini menggunakan pendekatan kualitatif studi lapangan di Kp. Undrus, Desa Cijantra, Kab Tangerang Teknik pengumpulan data pada penelitian ini menggunakan obnervasi, wawancara, dan dokumentasi Sedangkan analinis data yang reduksi data, dan verifikasi data stau penurikan kesimpulan. Lalu menggunakan teknik ui validitas data dengan mengutamakan kredibilitas data, transferabilitas data, kekuatan realitas, serta konfirmasi objek penelitian.

\section{PEMBAHASAN}

Orang tua merupakan lembaga pendidikan yang utama, sehingga diharapkan selalu berusaha menyediakan berbagai macam kebutuhan baik secara psikologis maupun biologis. Orang tua juga diharapkan mampu 
menciptakan pribadi yang terampil di tengah-tengah masyarakat (Jailani, 2015:246).

\section{A. Cara Orang Tua Dalam Mendidik Anak di Era Revolusi Industri} 4.0

1. Pandangan Akan Pentingnya Pendidikan

Pendidikan pada dasarnya adalah salah satu upaya untuk membentuk manusia yang memiliki kualitas dan bertanggung jawab, sehingga menciptakan generasi yang tangguh. Di dalam UndangUndang Pendidikan Indonesia No. 20 tahun 2003 Bab 1 Pasal 1. Yang berbunyi:

"pendidikan nasional merupakan pendidikan yang mengacu serta mengarah kepada UUD 1945 dan Pancasila serta berlandaskan pada nilai-nilai agama, kebudayaan Indonesia dan cermat melibat dalam perkembangan zaman" (Sisdiknas, 2003:3)

Sebagaimana yang diungkapkan oleh Selo Soemarjan, pendidikan di dalam orang tua merupakan hal yang paling utama untuk dipersiapkan dengan sifat alamiah. Anak dipersiapkan untuk menjalani proses perkembangannya untuk bekal ketika dewasa, juga harus mempelajari bahasa, adat istiadat sampai kebudayaannya. Ini menjadi tugas utama pendidikan di dalam orang tua untuk memperkenalkan itu semua (Jailani, 2015:246).

Pentingnya pendidikan di dalam orang tua dari beberapa faktor diantaranya adalah seorang anak harus memiliki tingkat kematangan berfikir. Lain dari pada itu pendidikan juga menjadi harapan orang tua untuk dapat bersosialisasi dengan baik di lingkungan orang tua maupun sosial kemasyarakatan. Apalagi jika dilihat dari pandangan kebanyakan orang tua bahwa anak harus memiliki pendidikan lebih baik dari sebelumnya untuk bekal nanti ketika menjelang dewasa agar tidak kesulitan dalam mendapatkan maksud serta tujuan.

Hal ini merupakan sebuah rancangan pada proses evaluasi pendidikan yang didapatkan oleh orang tua dahulu, sehingga memperbaiki kepada anak-anaknya, maka dampaknya akan tertuju pada karakteristik yang akan didapatkan nantinya, seperti memiliki daya produktif yang tinggi dimanapun berada, menyelesaikan 
masalah dengan cepat dengan memperhatikan hal-hal terkecil sekalipun, serta mampu bergaul dalam lingkungan masyarakat (Ahmad, 2017:76)

Hal ini perlu disadari akan hal pendidikan, dimana mereka mau tidak mau harus mempersiapkan dan mendidik anak-anaknya dari balita, sehingga ketika anak masuk pada lembaga formal akan lebih mudah mengikuti alurnya. Dalam pendidikan orang tua cakupan yang dibutuhkan daintaranya adalah: perhatian, kasih sayang, pendidikan sosial, pendidikan keagamaan, pendidikan karakter anak, dan kedisiplinan.

Orang tua yang memandang serius akan pentingnya pendidikan untuk seorang anak menjadi semangat utama untuk mencapai apa yang diinginkan, sehingga akan mengalahkan rasa pasrah dalam meninggalkannya.

2. Standar Mendidik di dalam Orang tua

Standarisasi mendidik di dalam lingkungan orang tua menjadi tingkatan kedua setelah pandangan pentingnya pendidikan yang diharapkan. Jika lebih dispesifikan lagi, terdapat 9 poin penting terhadap nilai-nilai pendidikan karakter (Megawangi, 2004:52), yaitu: (1) cinta tuhan, (2) kemandirian, (3) kejujuran, amanah, dan bijaksana, (4) hormat dan santun, (5) dermawan, suka menolong, dan gotong royong, (6) percaya diri, kereatif, dan pekerja keras, (7) kepemimpinan dan keadilan, (8) baik dan rendah hati, (9) toleransi, kedamaian dan kesatuan.

Standarisasi orang tua dalam mendidik anak juga perlu mengacu kepada Sistem Pendidikan Nasional, yang tertera pada No. 20 Tahun 2003 Bab 1 Pasal 1 yang berbunyi:

"pendidikan nasional merupakan pendidikan yang mengacu serta mengarah kepada UUD 1945 dan Pancasila serta berlandaskan pada nilai-nilai agama, kebudayaan Indonesia dan cermat melibat dalam perkembangan zaman"

Dengan landasan pendidikan dan dasar yang kuat maka akan sesuai dengan sistem pendidikan nasional dan menjadi sebuah harapan bagi orang tua dan juga tujuan pendidikan bangsa Indonesia. Tujuan paling uatama di dalam mendidik anak oleh orang tua adalah 
meningkatnya ketaatan kepada Allah Swt. dan menjalankan ritual keagamaannya dengan baik. Selain itu juga adanya keinginan menjadikan akhlak anak itu baik jika dilihat oleh siapapun dan dimanapun ketika mereka berada. Selain itu juga orang tua juga ingin anak-anaknya dapat menjadi ahli ilmu agama yang dapat bermanfaat bagi orang tua terlebih dahulu.

Dengan taat kepada Allah Swt. Anak akan menjadi pribadi yang berakhlak baik serta akan merujuk kepada kebaikan yang lainnya, baik itu di dalam lingkungan orang tua maupun lingkungan sosial masyarakat. Sebagaimana Islam memandang betapa pentingnya menyembah Allah dan larangan untuk menyekutukannya tertuang di dalam Al-Qur'an:

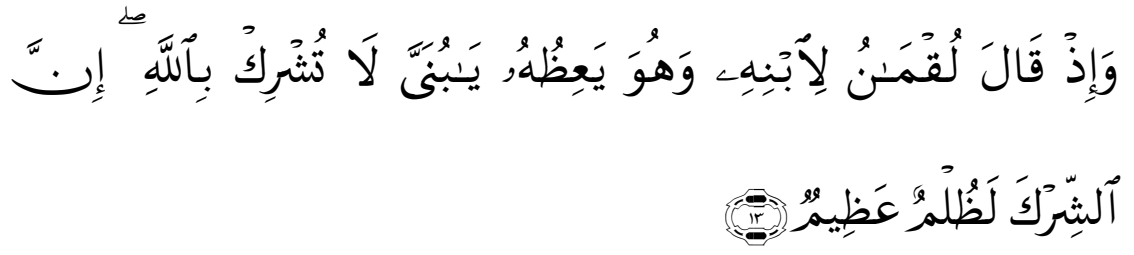

'Dan (ingatlab) ketika Luqman berkata kepada anaknya, di waktu ia memberi pelajaran kepadanya: "Hai anakku, janganlah kamu mempersekutukan Allah, sesunggubnya mempersekutukan (Allah) adalah benar-benar kęaliman yang besar" (Q.S. 31: 13).

Standarisasi masyarakat Kp. Undrus, Desa, Cijantra Kec. Pagedangan, Kab. Tangerang sebenarnya sangat merujuk kepada tujuan pendidikan nasional dan tujuan pendidikan yang tertera pada telaah dari teori Taxonomy Bloom. Seperti membentuk watak bangsa yang menjadikan pribadi dan berbudaya religius, beriman dan bertakwa kepada Tuhan Yang Maha Esa dan berilmu, tentu akan membentuk manusia dengan intelektual dan daya kritis tinggi, mandiri dan bertanggung jawab menjadikan pribadi yang kaffah (Ani, 2015:51).

Standarisasi dalam mendidik anak di orang tua pada masyarakat Kp. Undrus, Desa Cijantra, Kec. Pagedangan Kab. Tangerang menjadi harapan yang tinggi sesuai dengan tuntunan Al-Qur'an serta menjadi 
cita-cita bangsa Indonesia. Jika hal ini dapat terlaksana dengan baik, maka akan menjadi dampak yang besar pada semua elemen.

Selain itu, harapan anak agar berguna untuk masyarakat serta agama juga menjadi standar dalam mendidik, orang tua tidak ingin anaknya terlibat dalam tindak kriminal sehingga dikatakan anak yang tidak baik. Dengan itu maka anak didik dengan tegas dalam berperilaku serta memberikan teguran dan tindakan jika memang ada perilaku yang menyimpang.

\section{Cara Orang Tua Dalam Mendidik Anak}

Cara pembelajaran merupakan proses dimana dalam suatu lingkungan seseorang baik disengaja maupun tidak untuk turut serta dalam tingkah laku dan kondisi khusus. Lingkungan belajar mestinya dikelola sebaik mungkin, karena peranan memiliki hal yang sangat penting di dalam dunia pendidikan (Chamalah et al., 2013:15)

Cara mengajar juga harus sangat diperhatikan dalam mendidik anak sekalipun di dalam lingkungan orang tua, karena agar bisa dipahami dengan mudah oleh anak sehingga hubungan antara orang tua dengan anak dapat berjalan dengan baik (Sudjana, 2002:76)

Pada dasarnya cara orang tua dalam mendidik anak di Kp. Undrus Desa Cinjantra Kab. Tangerang dapat dikatakan beragam dan klasik karena cara yang digunakan orang tua menggunakan apa yang didapatkannya dahulu ketika mereka kecil, namun penggunaannya sangat populer sampai saat ini. Dalam pelaksanaannya masyarakat Kp. Undrus, Desa Cijantra, Kec. Pagedangan, Kab. Tangerang memiliki cara tersendiri dalam mendidik anak-anaknya di rumah.

Dengan demikian, dalam praktik pelaksanaannya tentu tidak terlepas antara kelebihan dan kekurangannya. Kelebihan yang ditunjukkan oleh orang tua dalam mendidik anak di orang tua adanya tanggungjawab antara kedua orang tua untuk mendidik anaknya, mengingatkan dan mengawasi kegiatan keagamaan selama di rumah, membatasi penggunaan barang-barang elektronik, selalu mengingatkan akan pentingnya akhak yang baik ketika dimanapun berada. 
Konsep kerja sama yang dilakukan antara kedua orang tua dan juga anak merupakan hal yang penting. Kedua orang tua bertanggung jawab dalam mengawasi setiap kegiatan anaknya juga mengingatkannya merupakan hal yang harus selalu dilakukan. Seperti mengingatkan dan menyuruh untuk ibadah, membatasi bermain barang-barang elektronik, selalu mengingatkan berperilaku sopan santun kepada siapapun dan jangan sampai melakukan tindakan kekerasan juga mengingatkan agar selalu berbakti kepada orang tua dan membantunya serta harus tahu akan tanggung jawabnya sebagai anak dan pelajar.

Pendapat ini juga merujuk apa yang dikatakan oleh Euis Puspitasari (2015:48), yang mengatakan bahwa pendidikan di dalam orang tua guna untuk membentuk pribadi yang bertanggung jawab, beriman dan bertakwa kepada Tuhan Yang Maha Esa, serta menguasai teknologi dengan penuh kesadaran akan pentingnya informasi. Teori lain juga menguatkan dengan adanya pendapat dari Ratna Megawangi (2004:52)

Selain itu juga orang tua Kp. Undrus, Desa Cijantra, Kec. Pagedangan, Kab. Tangerang beberapa memberikan contoh teladan kepada anaknya sebagai tuntunan apa yang dilihat oleh anakanaknya, sehingga anak akan meniru dan melakukan apa yang dilihatnya. Orang tua mengajarkan secara langsung kepada anaknya dengan mengatur jadwal yang tidak mengganggu proses di sekolah. Proses mendidik di rumah dilakukan kepada anak seperti belajar mengaji, membaca, menghitung, sampai mencari materi dan menggunakan internet dengan bijak.

Memberikan teladan kepada anak perlu dilakukan di dalam rumah mengingat anak adalah peniru apa yang dilihatnya. Selain itu juga memberikan hubungan yang harmonis antara orang tua khususnya kepada anak menjadi salah satu kunci agar anak semangat dalam belajarnya serta dapat menumbuhkan rasa percaya dirinya meningkat.

Jika dicermati dengan cara mendidik yang dilakukan begitu Islami, dengan memberikan batasan dengan contoh. Secara tidak langsung itu merupakan sebuah batasan dan peringatan yang harus diketahui 
oleh anak. Bila merujuk kepada teori pendidikan, hal tersebut termasuk kedalam cara Tad₹kirah (Majid \& Andayani, 2004:52):

(1)Tunjukan Teladan, orang tua juga harus menunjukkan teladan bagi anak-anaknya, dampaknya mereka akan menirukan apa yang dikerjakan oleh orang tua nya secara keseharian. (2) Arabkan, pengarahan terus dilakukan kepada anak-anak, seperti mana perintah yang harus dikerjakan dan mana yang dilarang atau akan membahayakan. (3) Dorongan (Berikan Motivasi), Tujuannya adalah untuk membangkitkan kembali semangat anak dalam melakukan kegiatannya. (4) Zakiyah (Bersib-Murni), maksudnya bersih yaitu orang tua harus ikhlas dalam melaksanakan proses mendidik anak di dalam orang tua. (5) Kontinuitas (Pembiasaan), pembiasaan dilakukan di dalam orang tua secara terus menerus sejak anak-anak dari balita dalam lingkup orang tua, tujuannya agar anak secara otomatis melakukan sendiri tanpa arahan. (6) Ingatkan, mengingatkan anak merupakan hal yang perlu dilakukan. Karena agar tetap terjaga dalam keadaan yang diinginkan, jika terus diingatkan maka secara tidak sengaja anak akan ingat teguran yang diberikan. (7) Repetisi \& Refleksi (Pengulangan), dilakukan seseorang hanya untuk memastikan agar anak tersebut dapat mendengar dan memahaminya dengan baik. (8) Organisasikan, hal ini lebih mengoorganisir hal-hal apa saja yang anak dapatkan di luar rumah ketika tidak bersama orang tua nya. (9) Heart, melibatkan perasaan kepada anak dalam mendidik merupakan suatu keharusan agar anak dapat timbul rasa nyaman terhadap orang tua nya.

Orang tua juga mengajarkan secara langsung kepada anaknnya dengan berbagai macam pembelajaran. Biasanya akan mengatur jadwal terlebih dahulu kepada anak agar tidak mengganggu waktu sekolah dan bermainnya, seperti yang diajarkan kepada anakanaknya yaitu: belajar mengaji, membaca, berhitung, membacakan cerita kepada anak,mengukur satuan panjang dengan jengkal atau alat lainnya, mencontohkan mencari materi dari internet dan penggunaan handphone dengan bijak.

4. Media Pembelajaran Dalam Orang tua 
Sudah menjadi hal yang diharuskan menggunakan media di dalam pembelajaran, baik di lembaga formal maupun non foromal. Itu berarti dalam mendidik anak pada lingkungan orang tua pasti tidak lepas menggunakan media pembelajaran baik itu hanya sebatas buku teks pelajaran.

Orang tua di Kp. Undrus, Desa Cijantra, Kec. Pagedangan, Kab. Tangerang mayoritas menggunakan buku-buku pembelajaran sesuai acuan lembaga formal. Tambahan lain seperti papan tulis kecil di dalam rumah cukup untuk menunjang sebagai media pembelajaran, apalagi ada beberapa orang tua yang menyediakan buku cerita, mainan pendidikan yang mengasah otak, bahkan ada juga orang tua yang menyediakan smartphone dan laptop sebagai media belajar anak dalam menunjang pendidikan untuk dikemudian hari.

Orang tua memberikan media pembelajaran lebih modern kepada anaknya dengam memberikan kebebasan dalam menggunakan handphone dan Laptop untuk pembelajaran di rumah serta mengembangkan kemampuan anak melalui media internet untuk mencari informasi. Hal ini orang tua memberikan kebebasan kepada anak-anaknya untuk belajar secara mandiri, agar terhindar dari kejenuhan.

Pada era digitalisasi saat ini, media visual memang sangat berpengaruh dalam menunjang keberhasilan daya berfikir anak serta akan tumbuhnya kreatifitas yang tinggi. Pemanfaatan internet juga digunakan untuk mencari sumber-sumber tambahan. Hal ini berarti masyarakat sudah benar-benar mengikuti perkembangan pendidikan untuk mempersiapkan anak-anaknya dalam konsep multiple intelegence (Maemunah, 2018:7)

Ketersediaan pembelajaran di dalam orang tua yang lebih inovatif menjadi penunjang keberhasilan anak dalam menghadapi tantangan pendidikan, sehingga akan mampu menjadi pribadi yang kreatif, mampu mengoprasikan teknologi, serta mampu menerapkan pencarian data secara online. Hal tersebut tergambarkan dengan adanya masyarakat Kp. Undrus Desa, Cijantra, Kab. Tangerang menyediakan media teknologi untuk anak-anaknya.

5. Pengembangan Kemampuan Anak 
Kemampuan seorang anak tidaklah sama satu sama lain, meskipun masih di dalam lingkup satu orang tua. Pada masyarakat Kp. Undrus Desa Cijantra, Kab. Tangerang sangat mendukung apa yang diminati anak jika hal tersebut merupakan kegiatan positif dalam dirinya. Kebanyakan orang tua mendukung kemampuan anak yang diminatinya.

Orang tua telah menyadari berbagai macam kemampuan anaknya yang berbeda-beda, menjadi hal yang sulit untuk mengetahui bakat serta kemampuan anak berada di bidang manapun. Sebagai orang tua hanya mendukung saja apa yang disenanginya saat itu, selagi dalam keperluan masa depannya serta pendidikannya. Jika memang sudah terlihat kemampuannya, maka orang tua akan mengulangulang apa yang sedang menjadi kesenangannya sehingga anak menjadi mahir dalam melakukan suatu kegiatan atau pekerjaaan pada bidangnya. Ditambah dengan memberikan film edukatif atau tata cara melakukan hobinya melalui video-video yang tersedia, sambil mengajaknya untuk melakukan atau membuat hal serupa sampai berhasil bersama orang tua. Jika memang ada keterbatasan pada orang tua dalam hal waktu atau pengetahuan akan dialihkan kepada orang lain atau kegiatan tambahan yang dilakukan di sekolahnya maupun di luar sekolahnya.

Pendapat di atas merupakan suatu usaha pengembangan kemampuan anak, tujuannya agar orang tua dapat membentuk anakanaknya dalam meningkatkan peradaban di dunia pendidikan, serta menumbuhkan watak dalam pengembangan potensi anak yang tinggi dengan harapan dapat memiliki kemampuan yang sesuai dengan apa yang dicita-citakan (Puspitasari, 2015:50)

\section{B. Kendala Orang Tua Dalam Mendidik Anak di Era Revolusi Industri 4.0}

1. Rendahnya Kepatuhan Anak Pada Perintah Orang Tua

Kendala di dalam mendidik anak selalu terjadi, baik sekecil apapun, ini menjadi hal yang biasa dalam pendidikan. Ada beberapa faktor yang menyebabkan kendala dalam mendidik anak seperti rendahnya 
tingkat pendidikan orang tua, kondisi ekonomi orang tua, faktor sosial, faktor keagamaan (Iriani, 2015:313)

Rendahnya pendidikan orang tua seringkali menyerahkan hampir seluruhnya kegiatan mendidik kepada pihak lain, seperti sekolah, guru les sampai kerabat. Jika ditambah lagi dengan kondisi ekonomi yang paling primer untuk memenuhi kebutuhan media dalam pendidikan. Selain itu faktor sosial juga memengaruhi dalam kendala mendidik anak, contohnya dalam lingkungan bermain dan tempat tinggal dapat menjadi penghambat berkembangnya pendidikan seorang anak (Iriani, 2015:313).

Kendala yang sering dihadapi orang tua di Kp. Undrus, Desa Cijantra dalam mendidik anak diantaranya adalah Sulitnya anak untuk diatur mulai dari waktu untuk belajar, mereka malah senang bermain bersama temannya dan bermain handphonenya di rumah. Bukan hanya itu saja dampaknya, anak juga manjadi sulit untuk mengerjakan ibadah jika telah masuk kepada waktunya, seperti kesulitan dalam mengatur waktu bermain handphone di dalam orang tua, serta membiasakan pembiasaan keagamaan secara rutinitas di rumah. Dampaknya anak menjadi malas untuk mengerjakan tugastugasnya dan menunaikan kewajibannya, serta sulit untuk diajak berkomunikasi.

Selain itu orang tua juga banyak yang kurang memahami cara menggunakan bandphone untuk media belajar secara online, tidak sedikit anak-anak mereka dialihkan kepada kakaknya, tetangganya atau saudaranya untuk membatu menyelesaikan tugas secara online. Ini menjadi keterbatasan orang tua dalam memahami mata pelajaran yang ada di sekolahnya yang terus berkembang, dampaknya orang tua menjadi kesulitan untuk membimbingnya.

Hal itu dikuatkan dengan data yang ada di Kantor Desa Cijantra tentang ketersediaan sarana dan prasarana yang kurang memadai serta kondisi masyarakat yang kurang memanfaatkan media internet sebagai bahan pencarian referensi untuk lebih mencari tahu informasi terbaru, sehingga tidak selalu berpatokan kepada apa yang dirujuk saja. 
Ini merupakan faktor penghambat yang terjadi sebagaimana yang diungkapkan Sulastri (2015:3) karena rendahnya pendidikan yang dituntaskan oleh orang tua, sehingga orang tua cukup kesulitan dalam mendidik serta mengarahkan anak.

Pemanfaatan internet atau media digital merupakan yang paling utama bahkan tidak bisa dihindari agar konsep multiple intelegence, disamping itu revolusi 4.0 sudah mengalihkan segalanya kepada hal digitalisasi produktifitas setiap manusia (Sulastri Ode Ami, 2015:3). Hal lain yang memengaruhi juga adalah kurangnya waktu untuk menyempatkan bersama orang tua di rumah, karena faktor kebutuhan ekonomi sehingga orang tua mengedepankan bekerja secara kesehariannya.

2. Mendidik Tanpa Media Pembelajaran

Masyarakat Kp. Undrus, Desa Cijantra, Kec. Pagedangan, Kab. Tangerang menyadari akan adanya kesulitan dalam mengajarkan anak-anak nya jika tanpa menggunakan media pembelajaran, dampaknya anak sulit untuk paham jika tidak menggunakan contoh pembelajaran.

Menjadi hal yang sulit saat ini bagi orang tua, jika mendidik anak tidak menggunakan media sekecil apapun, walaupun itu hanya sebatas buku pelajaran disekolahnya. Orang tua akan mengajarkan anak-anaknya secara lisan dan pengalaman yang didapatkannya dulu ketika sekolah, sehingga keterbatasan dalam memahami mater pelajaran sangatlah sedikit.

Jika hal itu terjadi beberapa orang tua juga menyuruh belajar bersama dengan temannya yang memiliki media cukup lengkap, atau meminta bantuan guru les dan tetangganya untuk membantu mendidiknya. Orang tua menyerahkan sepenuhnya kepada orang lain bukan tanpa alasan, karena memang tidak adanya media atau pengetahuan cukup yang dimiliki untuk mendidik anak tersebut.

Ini juga merupakan suatu usaha orang tua dalam melaksanakan kepedulian terhadap anak-anaknya untuk merancang konsep, bekal dalam bahan ajar, pembelajaran yang mengarah pada kebutuhan di masa sekarang (Maemunah, 2018:8) 
Pemenuhan kebutuhan media pembelajaran, sebenarnya sekecil apapun pendidikan tentu harus menyesuaikan dengan kebutuhan zaman. Secara tidak langsung harus terus menyesuaikan pembaharuan yang ada, jika tidak menyesuaikan dampaknya akan kepada sumber daya manusia yang kurang mampu bersaing, pastinya akan terus mengalami kemunduruan.

Sebagian lagi mengatakan hal lain dalam pemenuhan kebutuhan media tersebut, orang tua memang menyadari akan hal pentingnya media pembelajaran untuk menunjang keberhasilan anak sendiri di dalam pembelajaran. Ini artinya sebagian orang tua Kp. Undrus, Desa Cijantra Kab. Tangerang telah dan siap untuk mempersiapkan pembelajaran yang lebih modern serta inovatif dalam mengoprasikan teknologi, memiliki lulusan yang kompetitif, sumber daya yang responsive, adaptif dan handal (Maemunah, 2018:7)

Orang tua di Kp. Umdrus, Desa Cijantra, Kab. Tangerang menyadari akan pentingnya media pemebelajaran sekecil apapun, orang tua menuturkan bahwa akan menjadi hal yang sulit jika tidak menggunakan media pembelajaran, hanya mengajarkannya secara mendikte saja. Hal ini tentu akan menjadi hal yang sangat sulit kepada anak untuk memahami pembelajaran. Apalagi jika harus mengalihkan kepada orang, pastinya akan mengeluarkan beban tambahan seperti rasa merepotkan orang lain.

Ditambah lagi jika harus mengikuti les kepada guru atau tempat yang menyediakan jasa bimbingan, tentu ini akan mengeluarkan biaya tambahan lagi. Jika dilihat pada pendapat sebelumnya, bahwa mayoritas masyarakat di Kp. Undrus, Desa Cijantra Kab. Tangerang adalah petani dan pengrajin yang penghasilannya tidak menentu. Maka hal ini menjadi sebuah tugas orang tua untuk mempersiapkan media pembelajaran di dalam orang tua secara kreatif untuk menunjang kebutuhan pendidikan anak-anaknya. 


\section{SIMPULAN}

Berdasarkan temuan data dan pembahasan pada bab sebelumnya, maka dapat diambil beberapa simpulan penelitian mengenai peran orang tua dalam mendidik anak di era revolusi industri 4.0 sebagai berikut.

Banyak cara yang digunakan orang tua di Kp. Undrus, Desa Cijantra, Kec. Pagedangan, Kab. Tangerang dalam mendidik anak-anaknya. Orang tua juga memiliki standar mendidik yang digunakan cukup beragam diantaranya adalah harus menerapkan perilaku disiplin waktu terhadap anak, memberikan teladan kepada anak-anaknya, tegas di dalam mendidik. Selain itu juga orang tua menerapkan kasih sayang sebagai rasa peduli terhadap anak-anaknya serta memberikan komunikasi yang baik kepada anak. Sedangkan cara yang dilakukan dalam mendidik anak dengan menerapkan kerja sama di dalam orang tua, mengontrol penggunaan barang-barang elektronik, memantau pergaulan anak ketika di luar rumah, menyuruh mengaji serta belajar mandiri, membacakan buku-buku cerita kepada anak sampai belajar mengajarkan berhitung.

Orang tua memiliki kendala dalam mendidik anak, begitupun kendalanya sangat beragam. Seperti kesulitan dalam mengatur waktu bermain anak sampai sulit untuk diatur, serta orang tua kesulitan dalam memahami pembelajaran anaknya karena berbeda dengan apa yang didapatkannya dahulu. Selain itu masalah yang lain juga muncul seperti kurangnya waktu bersama anak dalam mendidik, karena waktu bekerja orang tua yang cukup padat, serta munculnya rasa jenuh pada anak dan orang tua juga kurang memahami dalam mengaplikasikan smartphone sebagai media belajar. Masalah lain juga muncul karena kondisi ekonomi orang tua yang belum tercukupi untuk memenuhi media pembelajaran, dikarenakan kondisi pekerjaan yang kurang menentu.

\section{REFERENSI}

Ahmad, T. (2017). Filsafat Pendidikan Islami (Ketujuh). Bandung: PT. Remaja Rosdakarya.

Ani, N. A. (2015). Pendidikan karakter untuk siswa sd dalam perspektif islam. Mimbar Sekolah Dasar, 1(1), 50-58. https://doi.org/10.1016/S00220248(02)02148-6 
Chamalah, E., Pd, S., Pd, M., Wardani, O. P., Pd, S., Pd, M., \& Press, U. (2013). Model dan metode pembelajaran.

Iriani, D. (2015). 101 Kesalahan Dalam Mendidik Anak. Retrieved from https://books.google.co.id/books?hl=id\&lr=\&id=AuBMDwAAQBAJ \&oi=fnd\&pg $=$ PP1\&dq $=$ kesalahan + yang + timbul + dalam + mendidik + ka rakter+anak\&ots $=7$ svjdHbCG4\&sig $=4 z$ Y95iTIXtHzUUKiMsoPpxxH Z_U\&redir_esc $=\mathrm{y} \# \mathrm{v}=$ onepage\&q $=$ kesalahan yang timbul dalam mendidik karakter anak\& $\mathrm{f}=$ fals

Jailani, M. S. (2015). Teori Pendidikan Keluarga dan Tanggung Jawab Orang Tua dalam Pendidikan Anak Usia Dini. Nadwa, 8(2), 245. https://doi.org/10.21580/nw.2014.8.2.580

Maemunah. (2018a). Kebijakan pendidikan pada era revolusi industri 4.0. Prosiding Seminar Nasional Pengambdian 2018 Univeristas Muslim Nusantara Al-Washliyah, (September), 1-8.

Maemunah, M. (2018b). KEBIJAKAN PENDIDIKAN PADA ERA REVOLUSI INDUSTRI 4.0. Prosiding Seminar Nasional Lembaga Penelitian Dan Pendidikan (LPP) Mandala.

Majid, A., \& Andayani, D. (2004). Pendidikan Agama Islam Berbasis Kompetensi: Konsep dan Implementasi Kurikulum 2004. Remaja Rosdakarya.

Megawangi, R. (2004). Pendidikan karakter solusi yang tepat untuk membangun bangsa. Jakarta: Indonesia Heritage Foundation.

Priatmoko, S. (2018). Memperkuat Eksistensi pendidikan Islam di era 4.0. TA'LIM: Jurnal Studi Pendidikan Islam, 1(2), 221-239.

Puspitasari, E. (2015). Pendekatan Pendidikan Karakter. Eduksos, III(2), 4557.

Sisdiknas, U. (2003). UU Sisdiknas. Retrieved from https://kelembagaan.ristekdikti.go.id/wpcontent/uploads/2016/08/UU_no_20_th_2003.pdf

Sudjana, N. (2002). Dasar-dasar proses mengajar. Bandung: Sinar Baru Algensindo.

Sulastri Ode Ami, I. (2015). INVERTILITAS PENDIDIKAN DALAM MENGHADAPI ERA REVOLUSI INDUSTRI 4.0 DI PULAU BURU. Retrieved from http://kabarterkini.news/invertilitaspendidikan-dalam-menghadapi-era-revolusi-industri-4-0-di-pulau-buru/

Syamsuar, \& Reflianto. (2019). Pendidikan Dan Tantangan Pembelajaran 
Yuda Rudiana

Berbasis Teknologi Informasi Di Era Revolusi Industri 4.0. Pendidikan Dan Tantangan Pembelajaran Berbasis Teknologi Informasi Di Era Revolusi Industri 4.0, 6(2), 1-13.

JIEBAR : Journal of Islamic Education: Basic and Applied Research Vol. 01, Nomor 02, Oktober2020 